\title{
РОЛЬ 4D КТ У ДІАГНОСТИЦІ ЕКТОПІЧНОГО РОЗТАШУВАННЯ АДЕНОМ ПРИЩИТОПОДІБНИХ ЗАЛОЗ У ВИПАДКУ ПЕРВИННОГО ГІПЕРПАРАТИРЕОЗУ
}

\author{
М.А. Уріна, О.А. Товкай \\ Український науково-практичний центр ендокринної хірургії, трансплантації ендокринних \\ органів і тканин, м. Київ
}

Вступ. Первинний гіперпаратиреоз - ендокринне захворювання, що зумовлене пухлинним або гіперпластичним процесом однієї або декількох прищитоподібних залоз, що призводить до нерегульованої гіперсекреції паратгормону, гіперкальціємії та ряду патологічних змін в органах-мішенях, перш за все, кістках і нирках. Найбільш частою причиною гіперпаратиреозу $\epsilon$ поодинока аденома прищитоподібної залози (ПЩ3). Рідше причиною гіперпаратиреозу $\epsilon$ гіперплазія Пщз, рак, киста. Підвищення рівня паратгормону сприяє підвищенню активності остеокластів і може призвести до остеопорозу. Ультразвукове дослідження (УзД) і радіоізотопне сцинтиграфічне дослідження ПЩЗ з використанням радіофармпрепаратів Тс-99m-MIBI $\epsilon$ методами вибору для візуалізації і визначення локалізації аденоми. При хибно-негативному результаті сцинтиграфії та сумнівних даних УзД (наявність супутнього багатовузлового зобу), навіть при шийній локалізації паратиреоїдної аденоми, а також у випадках ектопічного розташування аденом ПЩ3 4D KT може виявитися корисною. Відсутність ефективних консервативних патогенетичних методів терапії залишає хірургічне видалення патологічних ПщЗ єдиним прийнятним методом лікування.

Мета: визначити можливості i роль 4D KT 3 внутрішньовенним введенням контрастної речовини в діагностиці ектопічного розташування аденом ПЩЗ.

Дата надходження до редакції 16.10.2018 p.
Матеріали і методи. 81 пацієнту з підвищеним рівнем паратгормону і кальцію в крові одночасно проводили УЗД шиї i 4D КT. Група пацієнтів складалася 369 жінок і 12 чоловіків віком від 25 до 56 років. Оцінка даних УЗД і КТ проводилась в порівнянні 3 інтраопераційними результатами i гістологічними висновками.

Результати. В результаті дослідження в усіх пацієнтів були виявлені аденоми, 3 яких 56 аденом мали типове розташування, 25 аденом - ектопічне. ТиповорозташованіаденомиПщзбулодіагностовано при проведенні УзД шиї в 50 з 56 випадків, при 4D KT - у 56 випадках. Ектопічно розташовані аденоми були виявлені тільки за допомогою 4D KT в 243 25 випадків. Ретрофарингеальне розташування аденом визначалось у 2 випадках, загрудинне - в 7, ретроключичне - в 6, у трахео-стравохідних кутах 8, парааортально - в 1. В 1 випадку аденома ПщЗ не була діагностована навіть при 4D KT і була знайдена в лівій частці щитоподібної залози інтраопераційно.

\section{Висновки}

1. УЗД $\epsilon$ методом вибору в діагностиці типово розташованих аденом прищитоподібних залоз.

2. 4D KT демонструє високу діагностичну ефективність у виявленні ектопічного розташування аденом прищитоподібних залоз.

3. За характеристиками контрастного підсилення 4D KT дозволяє відрізнити аденоми прищитоподібних залоз від лімфатичних вузлів. 